\title{
Follower fish of the goldspotted eel Myrichthys ocellatus with a review on anguilliform fish as nuclear species
}

\author{
Maria L. F. Ternes ${ }^{1 *}$, Vinicius J. Giglio ${ }^{2,3}$, Thiago C. Mendes ${ }^{2,3}$ and Pedro H. C. Pereira ${ }^{4,5}$
}

\begin{abstract}
In a nuclear-follower fish foraging association, the follower benefits from food uncovered or flushed out when the nuclear fish disturbs the bottom, while nuclear species generally do not seem to be benefiting. Among nuclear species, eels (anguilliform fish) are known to be one of the most represented groups. Here we investigated the frequency and time duration of foraging associations among the goldspotted eel Myrichthys ocellatus and reef fish in a subtropical marginal reef. In addition, we reviewed nuclear eel species and their followers described in the literature. From a total of 211 goldspotted eels observed, seven follower species were recorded in 19\% of the samples. The average time of the following associations per species ranged from 40 to $190 \mathrm{~s}$. Four species were reported for the first time as $M$. ocellatus followers (Bodianus rufus, B. pulchellus, Stephanolepis hispidus, and Serranus baldwini) and three of them have never been reported in the literature as eel followers (B. pulchellus, S. hispidus, and S. baldwini). The literature describes 13 eel species acting as nuclear for 66 fish species, represented mainly by groupers and sea basses. The size of the eel was not correlated with the size of its follower and neither with the number of described follower species. The nuclear role of eels is likely to be an important component of the trophic ecology of small and medium-sized macrocarnivore fish.
\end{abstract}

Keywords: Reef fish behavior, Southwestern Atlantic, Foraging associations, Nuclear and follower, Reef fish, Interspecific associations

\section{Background}

Interspecific associations are common in structurally and ecologically complex ecosystems such as coral reefs. Among reef fish, interspecific foraging associations are characterized by the opportunistic joining of individuals from two or more species during feeding $[1,2]$. It comprises a "nuclear species" that disturbs the bottom while foraging and exposing potential preys to opportunist or generalist predator species known as "follower" [3]. The nuclear-follower association has been described for a diversity of species that varies from small mobile invertebrate feeders to large piscivores [4-8]. Considering that this association is relatively common, it is believed to

\footnotetext{
*Correspondence: marialaura.ft@gmail.com

1 Programa de Pós-Graduação em Zoologia, Universidade Estadual de Santa Cruz, Ilhéus, BA, Brazil

Full list of author information is available at the end of the article
}

play an important role in the trophic ecology of reef fish [9]. The nuclear-follower association is commensal by benefiting the follower with easier access to inaccessible prey, higher feeding success, lower energy expenditure on foraging, and lower susceptibility to predation [6]. On the other hand, it is hypothesized that nuclear species do not gain benefits from feeding and may even be impaired due to food competition with followers [2]. Nevertheless, nuclear species can benefit from social feeding such as vigilance against predators and avoid that some prey escape. Also, it has been suggested that the nuclear-follower associations can increase the foraging opportunities for both species [10].

Anguilliform fish (hereafter referred to as "eels" for simplicity) are among the most representative nuclear species in the nuclear-follower associations $[6,11]$. Eels often forage on clumps of algae, sand banks, and between reef crevices, where they prey on crabs and small fish. 
Their body shape enables them to access crevices that are inaccessible to most fish [12] and, therefore, they represent potential nuclear species for opportunistic follower fish. However, feeding associations involving eels have only been descriptively investigated despite their potential importance. For instance, it remains unknown whether the body size of nuclear species influences the number of reported followers and whether a particular fish genus is more prone to associate with eels than to other genera.

We investigated the nuclear-follower associations using the goldspotted eel Myrichthys ocellatus as a nuclear species in a subtropical marginal reef. The species is mostly nocturnal, feeds primarily on crabs, although it may also forage during the daytime $[13,14]$. Specifically, this study aims to examine the frequency and time of the nuclearfollower associations among reef fish. In addition, we conducted a review on the eel species that have been globally described as nuclear and the number of follower species and then investigated the relationship between the eel body size and the amount and type of follower species.

\section{Methods}

\section{Study site}

The study was conducted in Arraial do Cabo, southeastern Brazil $\left(22^{\circ} 57^{\prime} \mathrm{S}, 42^{\circ} 01^{\prime} \mathrm{W}\right)$. The region consists of an isthmus and three islands dominated by rocky shores. The sites surveyed were mostly composed of coastal rocky reefs with depths of 4-12 m and water temperature of $17-26^{\circ} \mathrm{C}$. This region has major ecological and conservation relevance on the Brazilian coast, as it is the southern distributional limit of some tropical species, with local fauna encompassed by both tropical and temperate species $[15,16]$.

\section{Data collection and analysis}

We conducted underwater observations through scuba diving (ca. $44 \mathrm{~h}$ ) and snorkeling (ca. $13 \mathrm{~h}$ ) between April and August 2015. Divers swam along coastal rocky reefs (2-8 m depth) searching for M. ocellatus. When an individual was found, we visually estimated its total length (TL) based on the collector experience in underwater visual census surveys and checked for the presence of any following fish. When an eel was followed by any fish, the observer started to record the duration. The eel observations lasted for five min, in which the behavior was classified as being moving, foraging, or resting. When a follower was present, we estimated its TL and recorded the behavioral interactions, for instance, if it touched a nuclear eel or presented agonistic behavior toward conspecifics to defend an advantageous position next to the eel. Divers maintained a minimum distance of $3 \mathrm{~m}$ from the fish to avoid disrupting the behavior of the eel and its followers. The relationship between the size of nuclear and the follower species was assessed with the Spearman rank correlations since the data were nonparametric.

The literature review was conducted through the search tools Scopus and Google Scholar using the words "follower + fish + eel"; "nuclear + follower + reef fish" and "following + behavior". We included only peer-reviewed literature in the analysis. From the selected papers, we recorded those that mentioned nuclear-follower interaction among eels and fish. The follower species were categorized according to the trophic categories as macrocarnivore, mobile invertebrate feeder, and omnivore $[17,18]$. The maximum size of nuclear eel species was described according to Froese \& Pauly [19]. The relationships between the maximum body size of nuclear species and (1) the number of follower species, and (2) the maximum body size of nuclear and follower species were assessed by using the Spearman rank correlation.

\section{Results \\ Followers of Myrichthys ocellatus}

A total of 211 sightings of $M$. ocellatus were recorded. The body size ranged from 30 to $100 \mathrm{~cm}$ TL (average $=64 \mathrm{~cm} \pm 6 \mathrm{SE}$ ). Most of the specimens recorded were foraging along the reef, disturbing the bottom $(92 \%)$, and few were resting $(8 \%)$. The followers were observed to be following 41 eels (i.e., 19\% of the observed M. ocellatus had followers), and the overall average time of association was $98 \pm 22 \mathrm{~s}$ (Table 1). Seven species were recorded as followers, of which four belonged to the family Labridae (Halichoeres brasiliensis, H. poeyi, Bodianus pulchellus, and B. rufus), one to Serranidae (Serranus baldwini), one to Epinephelidae (Mycteroperca acutirostris), and one to Monacanthidae (Stephanolepis hispidus). The most frequently recorded followers were B. rufus $(\mathrm{n}=12), S$. hispidus $(\mathrm{n}=9)$, and $H$. brasiliensis $(\mathrm{n}=5)$ (Table 1$)$. Most follower species were mobile invertivores ( $\mathrm{n}=5$ species), with only one species each of macrocarnivore and omnivore.

Overall, the size of $M$. ocellatus was significantly correlated to the size of its followers $(\mathrm{r}=0.42 ; p=0.007$; Table 1). Among all observed interactions, $B$. rufus presented the highest number of agonistic interactions toward conspecifics ( $\mathrm{n}=12$ events) and touched $M$. ocellatus more frequently $(\mathrm{n}=6$; Table 2$) . H$. brasiliensis and S. baldwini were the only species that did not present agonistic interactions. No agonistic interactions were registered between the nuclear and follower species.

\section{Anguilliform fish as nuclear species}

We found 22 studies reported eels as nuclear species, all of which included reef-associated species from the 
Table 1 Follower fish of Myrichthys ocellatus recorded in Arraial do Cabo, Brazil

\begin{tabular}{|c|c|c|c|c|c|}
\hline Family & Species (no. of events) & $\begin{array}{l}\text { Interaction duration } \\
\text { (s) }\end{array}$ & $\begin{array}{l}\text { Mean body size of the } \\
\text { nuclear species }\end{array}$ & $\begin{array}{l}\text { Mean body size of the } \\
\text { follower species } \\
\text { (cm) M. ocellatus }\end{array}$ & $\begin{array}{l}\text { Spearman rank cor- } \\
\text { relation result }\end{array}$ \\
\hline Labridae & Halichoeres brasiliensis (7) & $69.3 \pm 6.1$ & $69 \pm 6$ & $27 \pm 2$ & $r=0.7 ; p=0.04$ \\
\hline Labridae & Halichoeres poeyi (4) & $40 \pm 12$ & $56 \pm 11$ & $16 \pm 1$ & $r=0.25 ; p=0.7$ \\
\hline Labridae & Bodianus pulchellus (5) & $122 \pm 24$ & $57 \pm 8$ & $19 \pm 1$ & $r=0.36 ; p=0.5$ \\
\hline Labridae & Bodianus rufus (12) & $145 \pm 27$ & $69.6 \pm 4.1$ & $28.3 \pm 0.9$ & $r=0.07 ; p=0.8$ \\
\hline Monacanthidae & $\begin{array}{l}\text { Stephanolepis hispidus } \\
\text { (10) }\end{array}$ & $65 \pm 4.2$ & $59 \pm 6$ & $24 \pm 1$ & $r=0.54 ; p=0.1$ \\
\hline Epinephelidae & $\begin{array}{l}\text { Mycteroperca acutirostris } \\
\text { (1) }\end{array}$ & 190 & 75 & 35 & * \\
\hline \multirow[t]{2}{*}{ Serranidae } & Serranus baldwini (2) & $45 \pm 12$ & $68 \pm 5$ & $9 \pm 2$ & * \\
\hline & All events & $96.6 \pm 21.4$ & $64 \pm 3$ & $25 \pm 1$ & $r=0.42 ; p=0.007$ \\
\hline
\end{tabular}

* Statistical tests were not done due to the small sample size. P-values in italic are significant. The deviations are standard errors

Table 2 Frequency of interactions among follower fish of Myrichthys ocellatus in Arraial do Cabo, Brazil

\begin{tabular}{lll}
\hline Species & Behavior & \\
\cline { 2 - 3 } & $\begin{array}{l}\text { Agonistic against conspe- } \\
\text { cifics }\end{array}$ & Touch nuclear \\
\hline Halichoeres brasiliensis & 0 & 2 \\
Halichoeres poeyi & 0 & 0 \\
Bodianus pulchellus & 5 & 3 \\
Bodianus rufus & 8 & 4 \\
Stephanolepis hispidus & 3 & 2 \\
Mycteroperca acutirostris & 0 & 2 \\
Serranus baldwini & 5 & 0
\end{tabular}

tropical $(\mathrm{n}=16)$ and subtropical $(\mathrm{n}=6)$ shallow reefs. In these papers, 78 nuclear-follower associations were described, in which 13 eel species were recorded as being nuclear (11 species of Muraenidae and two of Ophichthidae), and 66 reef fish species from 17 families were recorded as followers. Most follower species belonged to Epinephelidae $(n=20)$, followed by Serranidae $(\mathrm{n}=10)$, and Labridae $(\mathrm{n}=10$; Fig. 1$)$. Considering the trophic category, followers were mostly macrocarnivores (MCAR, $\mathrm{n}=33$; $53 \%$ ), followed by mobile invertivore feeders (MINV, $\mathrm{n}=18$; 29\%); roving herbivores (ROVH) and sessile invertivore feeders (SINV) (each with 3 species); planktivores (PLK), and territorial herbivores (TERH) (each with 2 species); and omnivores (OMNI, $\mathrm{n}=1$; Table 3). Overall, the average number of follower species for each eel species was $5.2 \pm 1.3 \mathrm{SE}$, and the highest number of follower species was reported for M. ocellatus (20 species) and Gymnothorax griseus (16 species; Fig. 2). The relationship between the maximum body size of the anguilliform nuclear species (overall mean: $131 \pm 21 \mathrm{~cm}$ ), and: (1) the number of follower

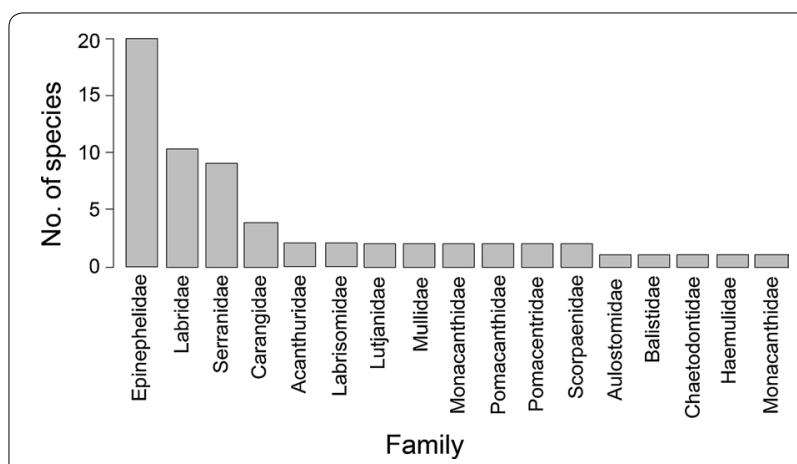

Fig. 1 Number of fish species described as followers of eels, according to the family, found in 22 peer-reviewed publications

species; and (2) the maximum body size of nuclear and follower species were not significant $(\mathrm{r}=-0.02, p=0.9$ and $\mathrm{r}=0.2, p=0.06$, respectively).

\section{Discussion}

\section{Followers of Myrichthys ocellatus}

This study describes four new species acting as followers of M. ocellatus: Bodianus rufus, B. pulchellus, Serranus baldwini, and Stephanolepis hispidus. The first three species have never been described as followers of anguilliform fish. M. ocellatus possess a suite of adaptations, such as round and elongated body that enables it to move through the reef and explore complex structures like narrow interstices (i.e., crevices, holes, cracks). These features promote $M$. ocellatus as a potential nuclear species even for small reef fish such as verified herein as also mentioned elsewhere $[13,20]$. M. ocellatus is distributed throughout the Atlantic ocean [21] and it is common in Brazilian shallow waters [17, 18, 22]. Given its abundance and its role as nuclear, the species is suggested to have a relevant functional role in the trophic ecology of reef fish through the facilitation of food access and an increase in 


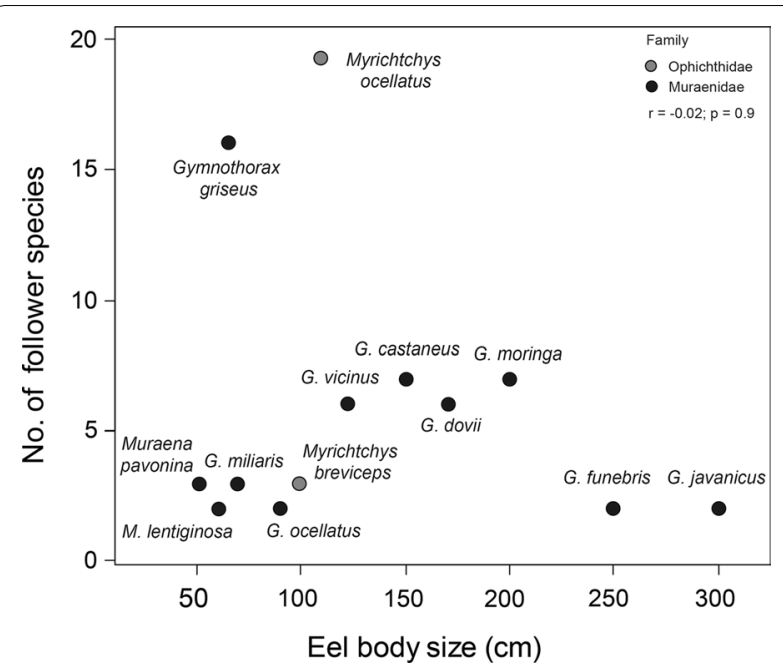

Fig. 2 Relationship between the maximum body size of the eel (total length) and the number of fish follower species described in the literature

the feeding success of follower fish $[5,23]$. However, the frequency in which the interactions occur was unknown, and surveys only described opportunistic behavioral aspects of the event $[13,14,20,24]$. To the best of our knowledge, this study presents the first data on duration and frequency (presence $\mathrm{x}$ absence) of following interactions with an eel species. Followers of $M$. ocellatus were relatively common (19\% of the individuals observed) and performed short-time opportunistic associations with no more than $190 \mathrm{~s}$. In fact, associations were observed when eels were actively disturbing the bottom to attract the attention of followers.

Comparisons of the size of both the nuclear and follower fish are also missing in the literature. Some studies have only speculated on the relationship between the size of nuclear and the follower fish species [25]. We found a relationship between the size of nuclear and follower to $H$. brasiliensis and for all species grouped. This can be explained because the amount of disturbance created by the foraging nuclear fish is suggested to influence the size and number of followers [9]. Species that cause a relatively high amount of disturbance such as $M$. ocellatus [13], are suggested to attract more followers [2].

During the present study, wrasses (Labridae) and filefish (Monacanthidae) were observed following M. ocellatus in pairs, occasionally displaying aggressive behavior toward conspecifics that attempted to join the foraging association. This aggressive behavior (short chases and displacements) aimed to maintain the fish dominance of the advantageous position next to the eel to avoid sharing the benefits of following the nuclear individual with conspecifics [14]. B. rufus was also aggressive toward the diver who was conducting the behavioral observations. Arraial do Cabo is considered as a popular diving site [26]; and this behavior is likely to benefit the nuclear species towards curious divers, especially photographers, who often approach such subjects to take photo [27]. A less frequent interaction observed was the touch by the follower on nuclear species. This type of contact by follower species is suggested to act as a stimulus to the nuclear fish to continue foraging $[1,28]$.

A previous literature review [13] reported 12 species of followers of $M$. ocellatus, of which five species were groupers. Nevertheless, in Arraial do Cabo, we recorded only one species of grouper (Mycteroperca acutirostris) in a single event. This low frequency of groupers in following associations may be related to the marked decrease in the abundance of groupers in the region during the last three decades as a consequence of overfishing $[29,30]$. Therefore, changes in the fish community caused by anthropogenic activities can be affecting interspecific associations, thereby influencing the reef trophodynamics.

\section{Anguilliform fish as nuclear species}

Anguilliform fish are followed by a variety of species, mainly macrocarnivores from the families Epinephelidae and Serranidae (groupers and sea basses), which represent half of the species described so far. These fish are considered to be inquisitive, they display opportunistic feeding behavior, and are known for following a wide range of reef fish species [4, 31, 32], as well as sea stars [33] and octopuses [4]. The main follower species of eels, the coney grouper Cephalopholis fulva is highly opportunistic and has been reported in interspecific feeding associations as a follower [3, 9], mimic [34], or even a preying cleaner species [35]. Remarkably, the four species of roving herbivorous and two territorial herbivorous were described as followers of M. ocellatus and Gymnothorax. Herbivorous are likely to feed on items made available by the nuclear species, such as pieces of algae loosened or unearthed by the nuclear fish [9].

Findings from this survey suggest that size of nuclear species is not a predictor of the number of follower species. The number of follower species is more likely to be related to the active foraging behavior of nuclear species. For instance, $M$. ocellatus (species with the highest number of followers - Table 3) is a small-sized species (max. $110 \mathrm{~cm}$ ) which behavior is described as "vigorous and agitated" [13]. This active behavior and the foraging activity increased the amount of disturbance produced by the nuclear species, thereby attracting more followers [5]. In addition, the diversity of habitats where $M$. ocellatus forage may also explain the high amount of followers verified. This species is known to forage in a diversity 
Table 3 Summary of nuclear-follower associations between eels and reef fish found in the literature

\begin{tabular}{|c|c|c|c|c|}
\hline Nuclear eel species & Follower species & $\begin{array}{l}\text { Trophic } \\
\text { category }\end{array}$ & Location & Source \\
\hline \multicolumn{5}{|l|}{ Muraenidae } \\
\hline Gymnothorax castaneus & Balistes verres & MINV & Gulf of California (TEP) & {$[5]$} \\
\hline Gymnothorax castaneus & Bodianus diplotaenia & MINV & Gulf of California (TEP) & {$[5]$} \\
\hline Gymnothorax castaneus & Epinephelus labriformis & MCAR & Gulf of California (TEP) & {$[5]$} \\
\hline Gymnothorax castaneus & Cephalopholis panamensis & MCAR & Gulf of California (TEP) & {$[5]$} \\
\hline Gymnothorax castaneus & Holacanthus passer & SINV & Gulf of California (TEP) & {$[5]$} \\
\hline Gymnothorax castaneus & Mycteroperca rosacea & MCAR & Gulf of California (TEP) & {$[5,36]$} \\
\hline Gymnothorax castaneus & Rypticus bicolor & MCAR & Gulf of California (TEP) & {$[5]$} \\
\hline Gymnothorax dovii & Caranx melampygus & MCAR & Malpelo island (TEP) & {$[7]$} \\
\hline Gymnothorax dovii & Dermatolepis dermatolepis & MCAR & Malpelo island (TEP) & {$[7]$} \\
\hline Gymnothorax dovii & Aulostomus chinensis & MINB & Malpelo island (TEP) & {$[7]$} \\
\hline Gymnothorax dovii & Mycteroperca olfax & MCAR & Malpelo island (TEP) & {$[7]$} \\
\hline Gymnothorax dovii & Seriola rivoliana & MCAR & Malpelo island (TEP) & {$[7]$} \\
\hline Gymnothorax dovii & Bodianus diplotaenia & MINB & Malpelo island (TEP) & {$[7]$} \\
\hline Gymnothorax funebris & Carangoides bartholomaei & MCAR & Brazil (SWA) & {$[4]$} \\
\hline Gymnothorax funebris & Cephalopholis fulva & MCAR & Brazil (SWA) & {$[4,37]$} \\
\hline Gymnothorax griseus & Aethaloperca rogaa & MCAR & Red Sea (WEI) & {$[6]$} \\
\hline Gymnothorax griseus & Cephalopholis argus & MCAR & Red Sea (WEI) & {$[6]$} \\
\hline Gymnothorax griseus & Cephalopholis hemistiktos & MCAR & Red Sea (WEI) & {$[6]$} \\
\hline Gymnothorax griseus & Cephalopholis miniata & MCAR & Red Sea (WEI) & {$[6]$} \\
\hline Gymnothorax griseus & Epinephelus fasciatus & MCAR & Red Sea (WEI) & {$[6,28]$} \\
\hline Gymnothorax griseus & Grammistes sexlineatus & MCAR & Red Sea (WEI) & {$[6]$} \\
\hline Gymnothorax griseus & Parupeneus cyclostomus & MINV & Red Sea (WEI) & {$[6]$} \\
\hline Gymnothorax griseus & Pterois volitans & MCAR & Red Sea (WEI) & {$[6,28]$} \\
\hline Gymnothorax griseus & Scorpaenopsis gibbosa & MCAR & Red Sea (WEI) & [6] \\
\hline Gymnothorax griseus & Thalassoma rueppellii & PLK & Red Sea (WEI) & {$[28]$} \\
\hline Gymnothorax griseus & Variola louti & MCAR & Red Sea (WEI) & {$[6]$} \\
\hline Gymnothorax javanicus & Epinephelus fasciatus & MCAR & Red Sea (WEl) & {$[6]$} \\
\hline Gymnothorax javanicus & Plectropomus pessuliferus & MCAR & Red Sea (WEI) & {$[1]$} \\
\hline Gymnothorax miliaris & Cephalopholis cruentata & MCAR & Caribbean (WEA) & {$[11]$} \\
\hline Gymnothorax miliaris & Cephalopholis fulva & MCAR & Caribbean (WEA) & {$[11]$} \\
\hline Gymnothorax miliaris & Rypticus saponaceus & MCAR & Caribbean (WEA) & {$[11]$} \\
\hline Gymnothorax moringa & Acanthurus bahianus & $\mathrm{ROVH}$ & Caribbean (WEA) & {$[11]$} \\
\hline Gymnothorax moringa & Bodianus rufus & MINV & Caribbean (WEA) & {$[11]$} \\
\hline Gymnothorax moringa & Cephalopholis cruentata & MCAR & Caribbean (WEA) & {$[11,38]$} \\
\hline Gymnothorax moringa & Cephalopholis fulva & MCAR & Caribbean (WEA) & {$[11]$} \\
\hline Gymnothorax moringa & Chaetodon capistratus & SINV & Caribbean (WEA) & [11] \\
\hline Gymnothorax moringa & Holacanthus tricolor & SINV & Caribbean (WEA) & {$[11]$} \\
\hline Gymnothorax moringa & Scarus taeniopterus & $\mathrm{ROVH}$ & Caribbean (WEA) & {$[11]$} \\
\hline Gymnothorax ocellatus & Diplectrum spp. & MCAR & Brazil (SWA) & [39] \\
\hline Gymnothorax ocellatus & Lutjanus spp. & MCAR & Brazil (SWA) & [39] \\
\hline Gymnotorax vicinus & Acanthurus coeruleus & $\mathrm{ROVH}$ & Brazil (SWA) & {$[4]$} \\
\hline Gymnotorax vicinus & Carangoides bartholomaei & MCAR & Brazil (SWA) & {$[4]$} \\
\hline Gymnotorax vicinus & Cephalopholis fulva & MCAR & Brazil (SWA) & {$[4]$} \\
\hline Gymnotorax vicinus & Haemulon parra & MINV & Brazil (SWA) & {$[4]$} \\
\hline Gymnotorax vicinus & Halichoeres radiatus & MINV & Brazil (SWA) & {$[4]$} \\
\hline Gymnotorax vicinus & Pseudupeneus maculatus & MINV & Brazil (SWA) & [4] \\
\hline Gymnothorax sp. & Bodianus diplotaenia & MINV & Gulf of California (TEP) & {$[36]$} \\
\hline Gymnothorax sp. & Epinephelus labriformis & MCAR & Gulf of California (TEP) & {$[36]$} \\
\hline
\end{tabular}


Table 3 continued

\begin{tabular}{|c|c|c|c|c|}
\hline Nuclear eel species & Follower species & $\begin{array}{l}\text { Trophic } \\
\text { category }\end{array}$ & Location & Source \\
\hline Muraena pavonina & Caranx latus & MCAR & Brazil (SWA) & [4] \\
\hline Muraena pavonina & Cephalopholis fulva & MCAR & Brazil (SWA) & [4] \\
\hline Muraena pavonina & Labrisomus conditus & MINV & Brazil (SWA) & [4] \\
\hline Muraena lentiginosa & Alphestes immaculatus & MCAR & Mexico (TEP) & [40] \\
\hline Muraena lentiginosa & Serranus psittacinus & MINV & Mexico (TEP) & [40] \\
\hline \multicolumn{5}{|l|}{ Ophichthidae } \\
\hline Myrichthys breviceps & Cephalopholis fulva & MCAR & Caribbean (WEA) and Brazil (SWA) & {$[4,11,13,24]$} \\
\hline Myrichthys breviceps & Epinephelus adscensionis & MCAR & Brazil (SWA) & [41] \\
\hline Myrichthys breviceps & Hypoplectrus puella & MCAR & Caribbean (WEA) & [11] \\
\hline Myrichthys ocellatus & Acanthurus bahianus & $\mathrm{ROVH}$ & Brazil (SWA) & [20] \\
\hline Myrichthys ocellatus & Bodianus pulchellus & MINV & Brazil (SWA) & This study \\
\hline Myrichthys ocellatus & Bodianus rufus & MINV & Brazil (SWA) & This study \\
\hline Myrichthys ocellatus & Epinephelus adscensionis & MCAR & Brazil (SWA) & {$[13,24,41]$} \\
\hline Myrichthys ocellatus & Epinephelus marginatus & MCAR & Brazil (SWA) & {$[14,17,33]$} \\
\hline Myrichthys ocellatus & Halichoeres brasiliensis & MINV & Brazil (SWA) & [13] This study \\
\hline Myrichthys ocellatus & Halichoeres poeyi & MINV & Brazil (SWA) & [20] This study \\
\hline Myrichthys ocellatus & Halichoeres radiatus & MINV & Brazil (SWA) & [4] \\
\hline Myrichthys ocellatus & Labrisomus cricota & MINV & Brazil (SWA) & [20] \\
\hline Myrichthys ocellatus & Labrisomus nuchipinnis & MINV & Brazil (SWA) & [20] \\
\hline Myrichthys ocellatus & Lutjanus alexandrei & MCAR & Brazil (SWA) & [13] \\
\hline Myrichthys ocellatus & Mycteroperca acutirostris & MCAR & Brazil (SWA) & [13] This study \\
\hline Myrichthys ocellatus & Mycteropercabonaci & MCAR & Brazil (SWA) & [24] \\
\hline Myrichthys ocellatus & Rypticus bistrispinus & MCAR & Brazil (SWA) & [24] \\
\hline Myrichthys ocellatus & Serranus baldwini & MINV & Brazil (SWA) & This study \\
\hline Myrichthys ocellatus & Serranus flaviventris & MINV & Brazil (SWA) & [24] \\
\hline Myrichthys ocellatus & Stegastes fuscus & TERH & Brazil (SWA) & [20] \\
\hline Myrichthys ocellatus & Stegastes variabilis & TERH & Brazil (SWA) & [20] \\
\hline Myrichthys ocellatus & Stephanolepis hispidus & OMNI & Brazil (SWA) & This study \\
\hline Myrichthys ocellatus & Thalassoma noronhanum & PLK & Brazil (SWA) & [4] \\
\hline Myrichthys ocellatus & Ulaema lefroyi & MINV & Brazil (SWA) & [13] \\
\hline Myrichthys sp. & Epinephelus fasciatus & MCAR & Red Sea (WEI) & [6] \\
\hline
\end{tabular}

Acronyms for trophic categories as follows: MCAR macrocarnivore, SINV sessile invertebrate feeder, MINV mobile invertebrate feeder, OMNI omnivore, PLK planktivore, $R O V H$ roving herbivore, TERH territorial herbivore. Nuclear and follower species are listed in ascending alphabetical order. WEA western Atlantic, SWA southwestern Atlantic, TEP tropical eastern Pacific, WEI western Indian

of environments, such as rocky/coral reefs, algae-rodolith beds, and sand and mud bottoms; therefore, this is likely to increase the variety of followers [13].

Eels can be followed by groups of fish, as reported for other nuclear fish species $[9,13]$. However, the data on the number of followers of eels in a group of fish are rarely available. The ecological implications of this foraging association and how changes in reef fish community structure (e.g., due to overfishing) can influence the frequency and complexity of such interactions remain unclear. Further studies should include quantitative data on foraging association such as duration, the number of followers at the same time, as well as the food intake rates.

\section{Abbreviations}

TL: total length; cm: centimeter.

\section{Authors' contributions}

MLFT and VJG collected, analysed the data and drafted the manuscript. TCM and PHCP wrote the manuscript. All authors read and approved the final manuscript.

\footnotetext{
Author details

${ }^{1}$ Programa de Pós-Graduação em Zoologia, Universidade Estadual de Santa Cruz, Illhéus, BA, Brazil. ${ }^{2}$ Programa de Pós-Graduação em Ecologia, Universidade Federal do Rio de Janeiro, Rio de Janeiro, RJ, Brazil. ${ }^{3}$ Departamento de Biologia Marinha, Reef Systems Ecology and Conservation Lab, Universidade Federal Fluminense, Niterói, RJ, Brazil. ${ }^{4}$ Programa de Pós-Graduação em Oceanografia, Universidade Federal de Pernambuco, Recife, PE, Brazil. ${ }^{5}$ Projeto Conservacao Recifal (PCR), Tamandaré, Brazil.
} 


\section{Acknowledgements}

We thank Arraial do Cabo marine extractive reserve-ICMBio (through Viviane Lasmar and Rafaela Farias) for research permits and support. VJG was supported by the Brazilian Ministry of Science and Technology (CNPq) and TCM was supported by FAPERJ. We thank RM Bonaldo, the editor and two anonymous reviewers for their valuable comments and suggestions.

\section{Competing interests}

The authors declare that they have no competing interests.

\section{Availability of data and materials}

All data generated or analyzed during this study are included in this published article.

\section{Consent for publication}

Not applicable.

\section{Ethics approval and consent to participate}

Not applicable.

\section{Funding}

Not applicable.

\section{Publisher's Note}

Springer Nature remains neutral with regard to jurisdictional claims in published maps and institutional affiliations.

Received: 5 July 2017 Accepted: 16 November 2017

Published online: 16 January 2018

\section{References}

1. Bshary R, Hohner A, Ait-el-Djoudi K, Fricke H. Interspecific communicative and coordinated hunting between groupers and giant moray eels in the Red Sea. PLoS Biol. 2006;4:e431.

2. Lukoschek V, McCormick M. A review of multi-species foraging associations in fishes and their ecological significance. In: Proceeding of the 9th international coral reef symposium 2002, p. 467-474.

3. Krajewski JP. How do follower reef fishes find nuclear fishes? Environ Biol Fish. 2009;86:379-87.

4. Sazima C, Krajewski JP, Bonaldo RM, Sazima I. Nuclear-follower foraging associations of reef fishes and other animals at an oceanic archipelago. Environ Biol Fish. 2007:80:351-61.

5. Strand S. Following behavior: interspecific foraging associations among Gulf of California reef fishes. Copeia. 1988;1988:351-7.

6. Diamant A, Shpigel M. Interspecific feeding associations of groupers (Teleostei: Serranidae) with octopuses and moray eels in the Gulf of Eilat (Agaba). Environ Biol Fish. 1988;13:153-9.

7. Quimbayo JP, Zapata FA, Floeter SR, Besudo S, Sazima I. Reef fish foraging associations at Malpelo island, Colombia (Tropical Eastern Pacific). Bol Invest Mar Cost. 2014;43(1):183-93.

8. Sazima C, Bonaldo RM, Krajewski JP, Sazima I. The Noronha wrasse: a jackof-all-trades follower. Aqua. 2005;9:97-108

9. Sazima C, Krajewski J, Bonaldo R, Guimarães P. The goatfish Pseudupeneus maculatus and its follower fishes at an oceanic island in the tropical west Atlantic. J Fish Biol. 2006:69:883-91.

10. Baird TA. A new heterospecific foraging association between the puddingwife wrasse, Halichoeres radiatus, and the bar jack, Caranx Tuber: evaluation of the foraging consequences. Environ Biol Fish. 1993;38:393-7.

11. Dubin RE. Behavioral interactions between Caribbean reef fish and eels (Muraenidae and Ophichthidae). Copeia. 1982;1982:229-32.

12. Malcolm HA. A moray's many knots: knot tying behaviour around bait in two species of Gymnothorax moray eel. Environ Biol Fish. 2016;99:939-47.

13. Araújo ME, Pereira PH, Feitosa JL, Gondolo G, Pimenta D, Nottinghan MC. Feeding behavior and follower fishes of Myrichthys ocellatus (Anguilliformes: ophichthidae) in the western Atlantic. Neotrop Ichthyol. 2009;7:503-7.
14. Gerhardinger LC, Samagaia R, Hostim-Silva M, Barreiros JP. A following association between juvenile Epinephelus marginatus (Serranidae) and Myrichthys ocellatus (Ophichthidae). Cybium. 2006:30(1):82-4.

15. Rogers R, Correal GO, Oliveira TC, Carvalho LL, Mazurek P, Barbosa JEF, Chequer L, Domingos TFS, Jandre KA, Leão LSD, Moura LA, Occhioni GE, Oliveira VM, Silva ES, Cardoso AM, Costa AC, Ferreira CEL. Coral health rapid assessment in marginal reef sites. Mar Biol Res. 2014;10:612-24.

16. Lima LFO, Coutinho R. The reef coral Siderastrea stellata thriving at its range limit: population structure in Arraial do Cabo, southeastern Brazil. Bull Mar Sci. 2015;92(1):107-21.

17. Luiz OJ Jr, Carvalho-Filho A, Ferreira CEL, Flooeter SR, Gasparini JL, Sazima I. The reef fish assemblage of the Laje de Santos Marine State Park, Southwestern Atlantic: annotated checklist with comments on abundance, distribution, trophic structure, symbiotic associations, and conservation. Zootaxa. 2008; 1807:1-25

18. Anderson AB, Carvalho-Filho A, Morais RA, Nunes LT, Quimbayo JP, Floeter SR. Brazilian tropical fishes in their southern limit of distribution: checklist of Santa Catarina's rocky reef ichthyofauna, remarks and new records. Check List. 2015;11(4):1688.

19. Froese R, Pauly D. FishBase. World Wide Web electronic publication. http://www.fishbase.org, (02/2017).

20. Pereira PHC, Feitosa JL, Chaves LC, de Araújo ME. Reef fish foraging associations:"nuclear-follower" behavior or an ephemeral interaction? In: Proceedings of the 12th international coral reef symposium 2012, p. 1-5.

21. McCosker JE, Rosenblatt $\mathrm{RH}$. A revision of the snake eel genus Myrichthys (Anguilliformes: Ophichthidae) with the description of a new eastern Pacific species. Proc Calif Acad Sci. 1993:48(8):153-69.

22. Chaves L, Pereira P, Feitosa J. Coral reef fish association with macroalgal beds on a tropical reef system in North-eastern Brazil. Mar Freshw Res. 2013;64:1101-11

23. Ormond RF. Aggressive mimicry and other interspecific feeding associations among Red Sea coral reef predators. J Zool. 1980;191:247-62.

24. Maia-Nogueira R, de Anchieta CC, Nunes J, Coni EO, Ferreira CM, Sampaio CLS. The twinspot bass Serranus flaviventris (Serranidae) as follower of the goldspotted eel Myrichthys ocellatus (Ophichthidae) in north-eastern Brazil, with notes on other serranids. Mar Biodiv Rec. 2009;2:e99.

25. Silvano RA. Feeding habits and interspecific feeding associations of Caranx latus (Carangidae) in a subtropical reef. Environ Biol Fish. 2001;60:465-70

26. Giglio VJ, Ternes MLF, Mendes TC, Cordeiro CAMM, Ferreira CEL. Anchoring damages to benthic organisms in a subtropical scuba dive hotspot. J Coast Conserv. 2017:21(2):311-6.

27. Giglio VJ, Luiz OJ, Schiavetti A. Recreational diver behavior and contacts with benthic organisms in the Abrolhos National Marine Park, Brazil. Environ Manag. 2016;57:637-48.

28. Karplus I. A feeding association between the grouper Epinephelus fasciatus and the moray eel Gymnothorax griseus. Copeia. 1978;1978:164-164.

29. Bender MG, Machado GR, de Azevedo Silva PJ, Floeter SR, Monteiro-Netto C, Luiz OJ, Ferreira CEL. Local ecological knowledge and scientific data reveal overexploitation by multigear artisanal fisheries in the Southwestern Atlantic. PLoS ONE. 2014:9:e110332.

30. Giglio VJ, Bender MG, Zapelini C, Ferreira CEL. The end of the line? Rapid depletion of a large-sized grouper through spearfishing in a subtropical marginal reef. Perspect Ecol Conserv. 2017;15(2):115-18.

31. Auster PJ, Sánchez-Jiménez A, Rodríguez-Arrieta JA, Quesada AJ, Pérez C, Naranjo-Elizondo B, Blum S, Cortés J. Facilitative behavioral interactions between deepwater piscivores at Isla del Coco National Park and Las Gemelas Seamount, Costa Rica. Rev Biol Trop. 2016;64:187-96.

32. Sazima C, Grossman A. A non-digging zoobenthivorous fish attracts two opportunistic predatory fish associates. Neotrop Ichthyol. 2015;3:445-8.

33. Gibran FZ. Activity, habitat use, feeding behavior, and diet of four sympatric species of Serranidae (Actinopterygii: Perciformes) in southeastern Brazil. Neotrop Ichthyol. 2007;5:387-98.

34. Sazima I, Krajewski JP, Bonaldo RM, Sazima C. Wolf in a sheep's clothes: juvenile coney (Cephalopholis fulva) as an aggressive mimic of the brown chromis (Chromis multilineata). Neotrop Ichthyol. 2005:3:315-8.

35. Francini-Filho R, Moura R, Sazima I. Cleaning by the wrasse Thalassoma noronhanum, with two records of predation by its grouper client Cephalopholis fulva. J Fish Biol. 2000;56:802-9.

36. Montgomery WL. Interspecific associations of sea-basses (Serranidae) in the Gulf of California. Copeia. 1975;1975:785-7. 
37. Sabino J, Andrade LP, Sazima I, Teresa FB, Floeter SR, Sazima C, Bonaldo RM. Following fish feeding associations in marine and freshwater habitats. Mar Freshw Res. 2016;68(2):381-7.

38. Abrams R, Abrams M, Schein M. Diurnal observations on the behavioral ecology of Gymnothorax moringa (Cuvier) and Muraena miliaris (Kaup) on a Caribbean coral reef. Coral Reefs. 1983;1:185-92.

39. Santos FB, Castro R. Activity, habitat utilization, feeding behaviour, and diet of the sand moray Gymnothorax ocellatus (Anguilliformes, Muraenidae) in the South western Atlantic. Biota Neotrop. 2003;3:1-7.
40. Craig M, Erisman B. A competitive following association between two reef fishes and the Jewelled Moray in the Gulf of California, Mexico. Coral Reefs. 2010;29:813-813.

41. Gasparini J, Floeter S. The shore fishes of Trindade Island, western South Atlantic. J Nat Hist. 2001;35:1639-56.

\section{Submit your next manuscript to BioMed Central and we will help you at every step:}

- We accept pre-submission inquiries

- Our selector tool helps you to find the most relevant journal

- We provide round the clock customer support

- Convenient online submission

- Thorough peer review

- Inclusion in PubMed and all major indexing services

- Maximum visibility for your research

Submit your manuscript at www.biomedcentral.com/submit 